\title{
CONDITIONS FOR THE ESTABLISHMENT OF DISTRIBUTION CHANNELS IN THE ORGANIC FOOD MARKET
}

\author{
Mariola Grzybowska-Brzezińska ${ }^{1 凶}$, Olena Gorlowa ${ }^{2}$ \\ ${ }^{1}$ University of Warmia and Mazury in Olsztyn, Poland \\ ${ }^{2}$ Odessa National Economic University, Ukraine
}

\begin{abstract}
The Polish organic food market continues to be a niche. Nevertheless, the market can function efficiently and develop provided that several conditions are met, including the optimization of the supply of raw materials and final products, and the organization of effective distribution channels. One of the key areas that require an in-depth analysis is the question of efforts undertaken at all levels of the marketing chain. Therefore, the purpose of this paper is to present the distribution channels of the Polish organic food market, explore the organizational limitations faced by this market, and diagnose the reasons why distribution channel participants do not cooperate with each other. In view of the findings of the research conducted among three groups (producers, processors and intermediaries), an attempt was made to identify successful networking solutions. The prerequisites for the prospective growth of the organic food market can be indicated. According to the interviewees, initiating and implementing collaboration as an element of marketing activities should lead to desirable outcomes, including more efficient market processes, especially as regards organic product distribution. Actions based on the integration and combination of marketing efforts should translate into market development. The creation of short supply chains is one of the key solutions.
\end{abstract}

Keywords: organic food market, organizational network, marketing chain, building relationships

\section{INTRODUCTION}

As the societies become wealthier and more environmentally aware, they demonstrate greater interest in organic food, thus creating development opportunities for the European and global markets for organic products (Domagalska and Buczkowska, 2015). In Poland, domestic demand for organic food corresponds only to a small fraction of the whole food market. Therefore, the Polish organic food market continues to be a niche. In Poland, net annual spending on organic food is observed to have grown rapidly over the past five years, at a yearly rate of $20 \%$. In 2017, it was ca. PLN 1.1 billion (VAT incl.). (Bragiel and Ślusarczyk, 2017). The underlying conditions for further growth of organic food production include both opportunities (such as increased competitiveness of food producers and processors active in this market) and barriers (for example, the lack of well-organized distribution channels and high costs generated at different stages of the marketing chain which considerably impede the conversion of the market potential into a strong competitive position (Asioli et al., 2017). In order for the organic food market to grow, it is necessary to support the demand and supply side by organizing effective distribution channels and by taking into account the unique nature of these channels, as seen by different customer segments (GrzybowskaBrzezińska, 2013). The excessively dispersed supply of

\footnotetext{
${ }$ Mariola Grzybowska-Brzezińska, PhD hab., prof. UWM, Department of Market Analysis and Marteking, University of Warmia and Mazury in Olsztyn, Prawocheńskiego 19 St., 10-719 Olsztyn, Poland, e-mail: margrzyb@uwm.edu.pl, https:// orcid.org/0000-0002-6571-1140
} 
organic products; scattered food processing plants; limited access to raw produce (due either to logistic problems or to inadequate quantity or quality of food produce); limited or absent supply of large uniform batches of plant or animal products; shortage of organized groups of economic operators with the capacity to bear, for instance, the costs of storage or transport (sometimes over extremely large distances, out of necessity); and lack of development plans for the organization of distribution or sales of organic food: these are the major problems which adversely affect the economic viability of this sector (Przybylak, 2016). It is somehow paradoxical that Poland struggles with an excessively low supply of raw products while having a much higher number of organic farmers per food processing plant than elsewhere in Europe. An impediment to the operation of organic food processing plants is the considerable geographic dispersion of organic farms. The poor development of domestic food processing plants is also reflected by the low processing level of organic food sold abroad, translating into an excessively narrow product range, or the fact that Polish organic food businesses often act as exporters only (Zuba, 2011). Processing is another weakness of the organic food market, as manifested by low growth rates. Organic food processing is characterized by a geographical mismatch. In particular, regions with considerable concentrations of organic farms have fewer processing plants than regions where there are fewer farms (Luczka, 2016).

The infrastructural shortcomings of the organic food market affect the organic food production chain, from the farmer, through to processing and distribution agents and consumers. The chain is severely lacking in connections. Sales channels for ready-to-eat organic products are underdeveloped, and so is the organization of deliveries, purchases, storage and processing (Michalczyk, 2016). On the production side, there are farms with a weak market power. The excessive dispersion of production locations causes difficulties in selling agricultural produce, which is the most common reason why farmers abandon the idea of running an organic farm; on the other hand, this is the underlying cause for the poorly developed wholesale market which plays an important role both in supplying the domestic market and with respect to the prospective growth of organic food exports (McFadden and Huffman, 2017). Another weakness of the organic food market is the lack of an information system about the demand for organic food arranged by type of foodstuffs, quantities, destinations, prices, delivery dates etc., i.e. the information necessary to build in the long-term - effective distribution systems which would match the producers' offer and the buyers' demand quickly and efficiently (Zuba, 2011). While the organic food trade system varies across regions, it always comprises two types of chains: short and long ones (Fig. 1, 2). The target market can be identified if every

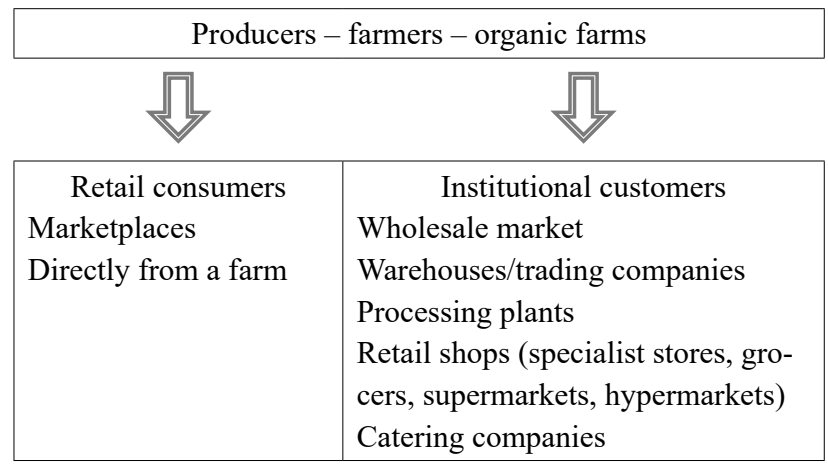

Fig. 1. Short distribution channel in the organic food market Source: own elaboration.

\begin{tabular}{|l|}
\hline Producers - farmers - organic farms \\
\hline Warehouses: \\
Wholesale market \\
Warehouses / trading companies \\
\hline
\end{tabular}

\section{Food processors}

Food processing plants (abattoirs, mills, freezer facilities, meat processing plants, dairies, etc.), catering services (schools, preschools, restaurants, hospitals, etc.).

\section{Retailers:}

Specialist shops,

Grocers (hypermarkets, supermarkets, delis, regional retail chains), etc.

Vending machines

Retail consumers

Fig. 2. Long distribution channel in the organic food market Source: own elaboration. 
participant to the chain provides an appropriate offer. The range, quality and production scale of products and the degree of on-farm processing determine the choice of channels used by the producers. High dispersion of organic food production, coupled with the lack of large uniform product batches, eliminates short chains where buyers are institutional customers, e.g. food processing plants or hypermarkets. Another significant challenge is to develop food processing and selling solutions, especially in regions where organic production has reached a high level, e.g. in Kujawsko-Pomorskie (GrzybowskaBrzezińska, 2013). The market for organic food can function and develop efficiently provided that the supply of raw materials and final products is optimized and the organization of organic food trade is provided with institutional support (Grzybowska-Brzezińska and Rudzewicz, 2015).

In Poland, the root cause for problems with the development of the organic food market is the weaknesses of particular stages of marketing chain, especially the missing organizational structures whose role is to integrate different stages of this chain in the organic food market. Gaining better understanding of the distinguishing features of the Polish organic food market, in conjunction with the search for effective and efficient solutions to overcome the barriers to its growth, should strengthen the competitive advantage of all businesses active in this market, whether domestically or internationally. One of the key areas that requires an in-depth analysis pertains to measures taken at all levels of the marketing chain which, in a model approach, is composed of food producers (farms), food processors, intermediaries and consumers. The identification of a marketing information system that should assist the formation of an organizational network and the development of relationships on the Polish organic food market can contribute to moving towards an optimum trade system through the integration and cooperation between market players, and such was the purpose of this study.

\section{RULES FOR ESTABLISHING COOPERATION IN DISTRIBUTION CHANNELS}

The creation of an organizational network of operators may be a way to establish an effective cooperation at specific stages of distribution channels. In the most general sense, an organizational network can be defined as a set of interrelated operators (individual organizations) who multiply the potential of every individual organization through synergies in their undertakings, thus creating a competitive advantage in the social and economic dimension. On the one hand, an organizational network operates and develops based on social relations initiated and strengthened by and between the networking parties. On the other hand, it makes them share the same interest, both at individual and network level. The network stimulates growth and leverages social capital which supplements (but also distorts) market relations in line with the aspirations of the networking parties. The main feature of a network organization is vertical disintegration which enables companies to contribute to the value chain at network level while preserving their uniqueness (Skowron, 2013). A networked company builds its competitive advantage based on a well-targeted group of customers, a unique business offer and specialized skills focused on a specific area of competitiveness. A network creates particularly beneficial conditions for mass individualization which is achieved through cooperation of companies specializing in specific products or services. Another advantage arises from the fact that a network builds strong relationships with customers in an effort to adjust the company's offer to customer expectations. The ever-evolving technological and organizational standards in a network requires the networking companies to modify their distinguishing features on a regular basis. Cooperative relationships between network participants result in what could be referred to as a shared customer who becomes increasingly demanding and expects improved experience and communication in the network (Katz and Shapiro, 1985). A solution to the problems in the organic food market could be the development of a network of organizations operating at different stages of the marketing chain, so as to achieve a networking effect which would create opportunities to increase the efficiency and effectiveness of the organic food market. Integration and cooperation measures within networks active at different stages of the marketing chain can be implemented provided that relationships are established between participants at different stages and between organizational networks operating in this sector. An efficiently operating marketing chain should provide the Polish organic food market with growth opportunities which would be beneficial to all market players, especially consumers, food producers and food processors (Kuberska and Grzybowska-Brzezińska, 2017). 


\section{MATERIALS AND METHODS}

The purpose of this research was to identify the conditions that affect the organization of the organic food market, and to diagnose the reasons why distribution channel participants do not cooperate with each other.

The research covered three groups of operators: food producers (farms), food processors and intermediaries. The methods used were based on structured interviews administered to producers and on in-depth structured interviews administered to producers, processors and consumers. The study covered the area of KujawskoPomorskie and Warmińsko-Mazurskie voivodeships in Poland, chosen due to their proximity to the research center and because of the development level of the local organic food market. The suggestion to organize organic food trade in a way consistent with the findings of the research carried out in selected locations will be the starting point for further proposals for other parts of Poland. The required number of samples was estimated based on the number of organic farms and processing plants published by the Inspectorate of Agri-Food Trade Quality as of 2016. The investigation was carried out in 2018, and included 25 organic farms in the Kujawsko-Pomorskie voivodeship and 65 organic farms in the WarmińskoMazurskie voivodeship; as for organic food processing manufacturers, 10 interviews were held in the Kujawsko-Pomorskie voivodeship and 20 in the WarmińskoMazurskie voivodeship; in addition, 40 intermediaries were interviewed, including representatives of regional shops specializing in organic food, regional supermarket chains, and representatives of hypermarkets and deli chains operating on a countrywide basis.

\section{RESULTS}

The potential output of production and processing can be enhanced through long-term cooperation (contracts) between farmers and food processors that ensures economically viable and acceptable conditions for both sides. Therefore, it is essential to investigate the attitudes and feedback of individual market players regarding barriers to the development of the organic food market, and to suggest ways to overcome the obstacles identified. This is particularly important in regions which produce high volumes of organic raw materials but lack a system for the processing, distribution and sale of organic products. The farmers, food processors and intermediaries surveyed clearly pointed to the lack of organization of organic food market at every stage of the marketing chain as a major barrier to market growth (Fig. 3).

The respondents believe the lack of a wide range of products to be equally important. This prevents the supply of versatile organic foodstuffs which, in turn, adversely affects consumer demand. Another significant problem is the lack of organic food chains which would ensure that specific product batches are regularly delivered to the market. Inadequate information and insufficient cooperation between actors of the marketing chain are two other impediments to the growth of the organic food market. The food processors identify yet another barrier: the difficulties in buying large uniform batches of raw products which would make the processing profitable and enable them entering into long-term contracts with hypermarkets or export companies.

Other factors often indicated by the respondents are shortcomings in the area of joint trade efforts, brands, and cooperation between farmers or food processing companies. It is recommendable to create and implement solutions which would facilitate market processes, especially with respect to the structure of retail distribution of organic food products. In the current economic reality, the development of the Polish organic food market is inhibited by disproportionately high prices of organic food products on shelves. This is the consequence of margins charged by intermediaries and of the inadequate structure of organic food distribution and trading systems. Also, the respondents pointed to another barrier to the development of the organic food market, namely the absence of a shared brand for Polish organic products and the absence of promotional efforts taken to create a shared regional brand. Products labeled with reliable information on local organic food production systems achieve a high degree of market penetration and can be promoted jointly by all producers. The lack of cooperation between marketing chain participants impedes the organization of efficient market structures and infrastructure. One of the purposes of this study was to identify the opinions of farmers, intermediaries and food processors on the causes of limited communication and collaboration between the above groups (Fig. 4).

A very important finding from the surveys on cooperation barriers, as carried out with representatives of the marketing chain, is that partners and contractors declare not to trust each other. The lack of experience and 


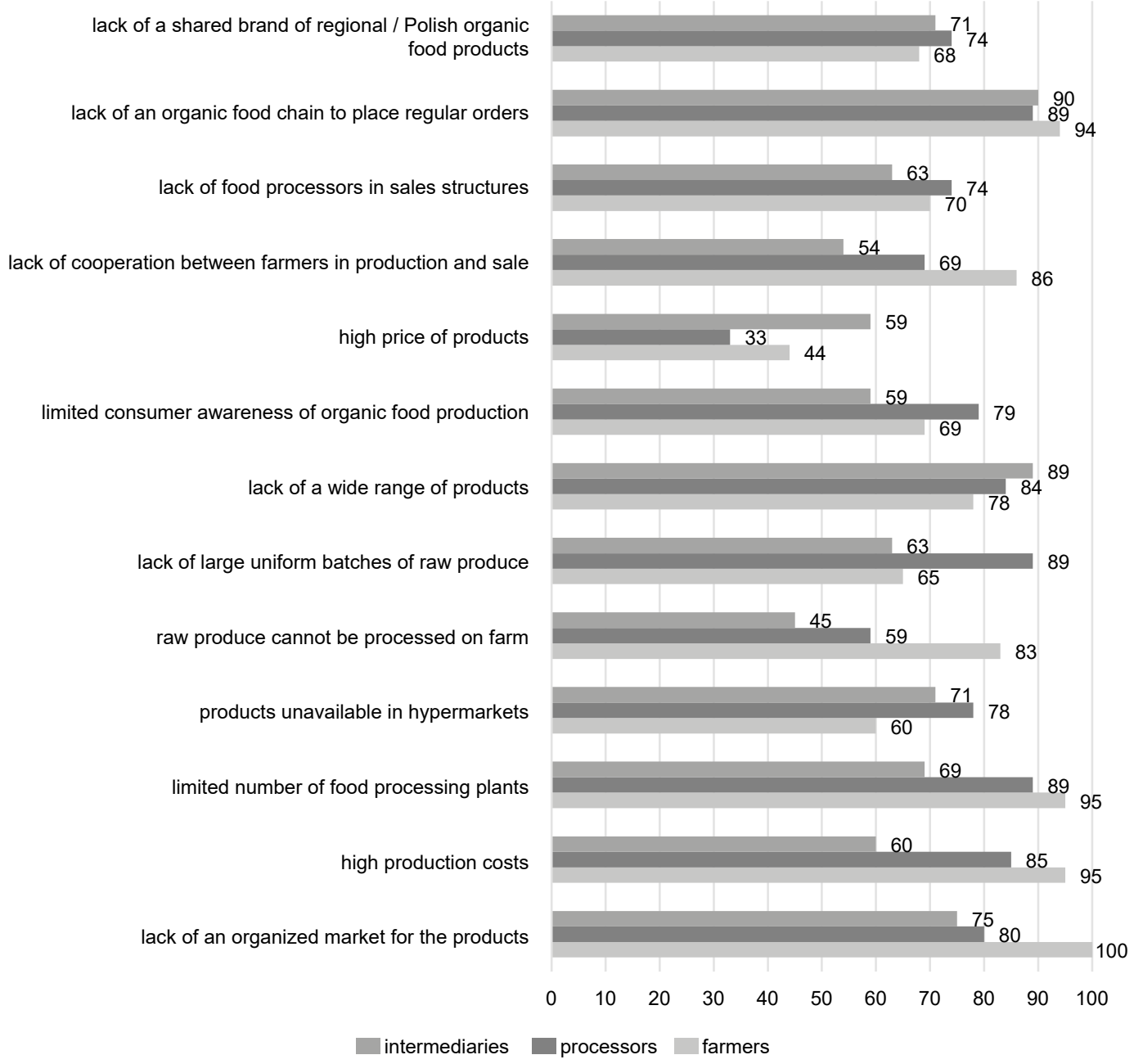

Fig. 3. Barriers to the development of the organic food market, as identified by organic farmers, organic food processors and intermediaries $(\%)$

Source: own elaboration.

best practices as well as the lack of initiative shown by farmers or intermediaries were also suggested as significant barriers to building cooperation. No relationships, communication or connections are established between local, regional or national market operators. Because production is fragmented between a large number of organic farms, the supply is limited and the production volume does not generate economies of scale, which adds to the difficulties in communication between farmers and builds a barrier in business dealings with processors or retailers. Positive relationships should be built between marketing channel actors who seek personal benefits based on the efficiency of chain operations; in other words, tools need to be developed to boost cooperation between market participants.

In the search for effective and efficient forms of support for the establishment of organizational networks in the organic food market, the surveyed representatives of different stages of the marketing chain were asked about the actions they believed would help building mutual relationships and would become the starting point for contacts and successful cooperation (Fig. 5).

According to ca. $90 \%$ of the respondents in each group, the major form of support are the funds granted 


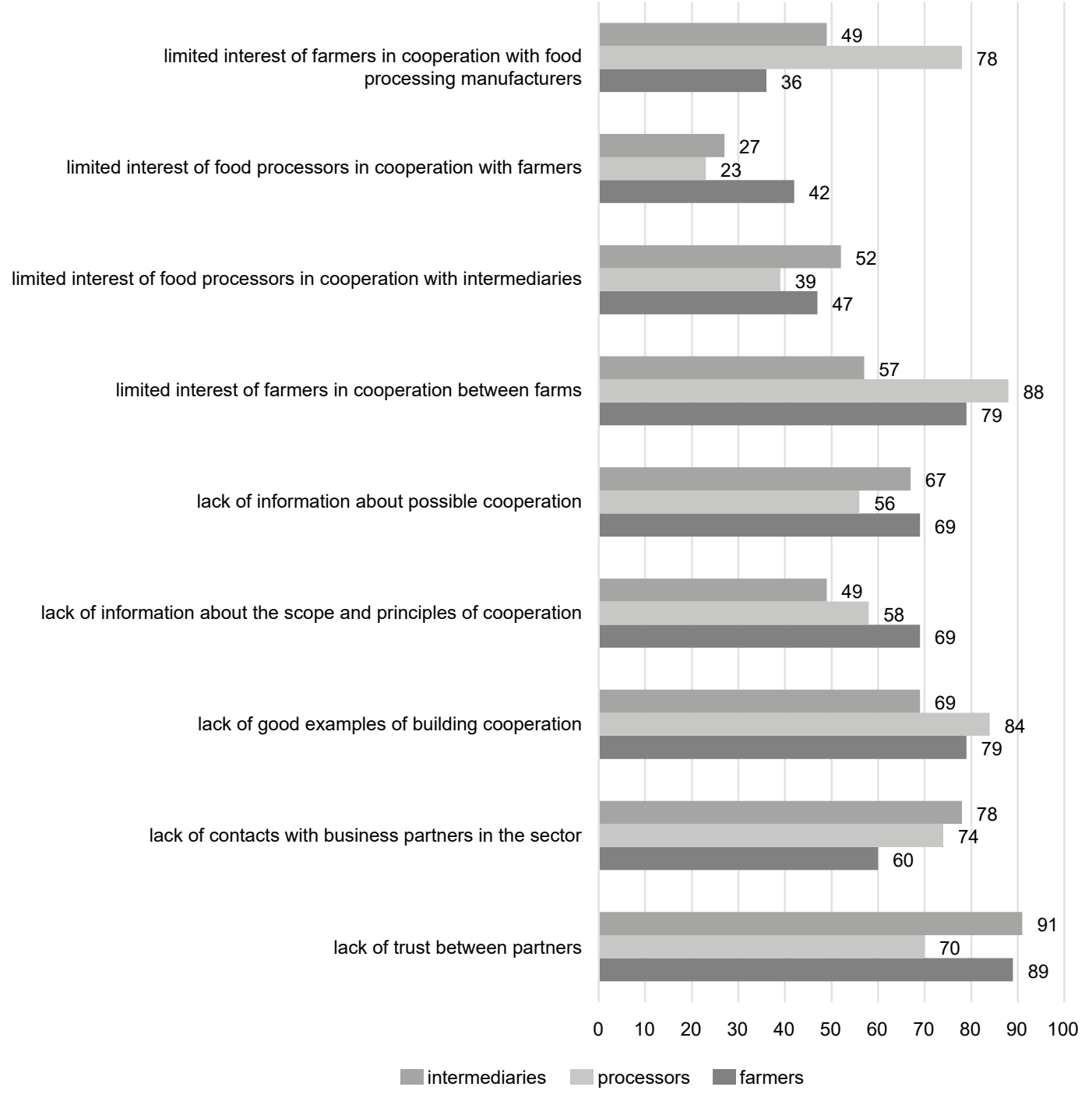

Fig. 4. Causes of limited cooperation in the organic food market, as identified by owners of organic farms, organic food processors and intermediaries $(\%)$ Source: own elaboration.

for the establishment of organizational networks. The respondents perceive cooperation as an expense and do not want it to involve their private funds. Furthermore, they expect help in establishing a network. In their opinion, there is insufficient information as to the essence of a network or possible cooperation between actors at different stages. Promotional campaigns regarding the benefits of this form of cooperation are indicated as an effective awareness-building tool.
The unique feature of an organizational network is that it combines competition and cooperation into an entire set of relationships between network participants. Therefore, organizational networks offer an advantage over a single company in that they can potentially have a much stronger and much more versatile impact on the customer. The concept of integrated marketing can be a starting point for analytical work and for projects implemented to develop a new marketing model 


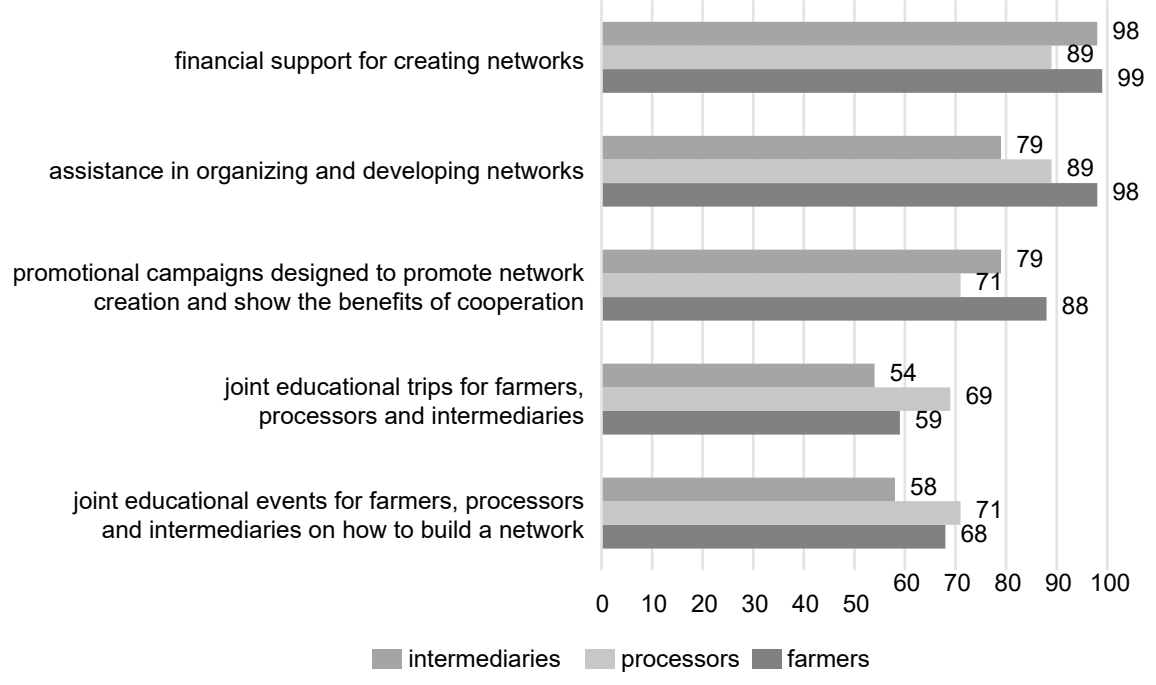

Fig. 5. Types of actions to be undertaken to build cooperation and establish organizational networks, as identified by the groups of respondents (\%)

Source: own elaboration.

in organizational networks for the organic food market (Skowron, 2015).

\section{CONCLUSION}

Despite many activation measures and diagnostic efforts, the organic food market continues to be a niche with a small share in the Polish food market. However, it may develop if the supply of raw materials and finished products is optimized, taking into account consumer expectations and the organization of effective distribution channels. One of the key areas that require an in-depth analysis is the question of actions taken at all levels of the marketing chain (composed of producers, processors and intermediaries). The purpose of this paper was to present the distribution channels of the Polish organic food market, explore the organizational limitations faced by this market, and diagnose the reasons why distribution channel participants do not cooperate with each other.

Producers and processors declare their will to cooperate and the need to organize local and regional distribution channels. The barriers to the development of the organic food market are the lack of market organization, lack of cooperation at producer, processor and trading level, and the lack of trust in partners as the main reason why relationship building is so difficult.
The key challenge for the organic food market is to achieve adequate organization of trade in agricultural produce both at regional and national level. It is necessary to develop the agricultural and food processing sector which will ensure regional supply of raw produce, semi-finished food products and sales of highly processed organic food products. There is no communication or cooperation between the food processing sector and producers. The farmers - who together could create a huge potential supply of raw materials and products also communicate with each other to a limited extent. It is also essential to create an effective training and advisory system, and to provide assistance to the sector in promoting cooperation and building organizational networks (farmers, food processors and intermediaries) and between actors at different stages of the marketing chain. Establishing collaboration and various forms of cooperation between participants at a specific stage of the marketing chain will enable developing short supply chains which are highly advantageous for this market. The recommended activities to be taken in connection with the development of organizational networks and relationships in the organic food marketing chain include promoting relationships and trust between individual market players. Integrated forms of communication and effective tools that drive the activity of organizational 
networks should be an incentive to build a competitive edge in the organic food market.

According to the respondents, the desirable outcome of developing and implementing cooperation mechanisms as part of marketing activities in the organic food market should be an improvement in market processes, especially in respect of organic product distribution. In the current economic reality, the growth of the Polish organic food market is hindered by disproportionately high prices of finished products, due to high margins charged by intermediaries. The establishment of short chains could prevent such practices. The implementation of activities based on marketing integration and cooperation should translate into the development of the organic food market. This will benefit all of its participants, in particular the consumers, producers and processors.

\section{SOURCE OF FINANCING}

Own funds of the Department of Market Analysis and Marteking, University of Warmia and Mazury in Olsztyn.

\section{REFERENCES}

Asioli, D., Aschemann-Witzel, J., Caputo. V., Vecchio, R., Annunziata, A., Naes, T., Varela, P. (2017). Making sense of the "clean label" trends: A review of consumer food choice behavior and discussion of industry implications. Food Res. Int., 99, 58-71.

Brągiel, E., Ślusarczyk, B. (2017). Tendencje na europejskim rynku żywności ekologicznej [Tendencies on the European organic food market]. Zesz. Nauk. SGGW Warsz. Probl. Roln. Świat., 17(3), 29-38; https://doi.org/10.22630/ PRS.2017.17.3.50 [in Polish].

Domagalska, J. Buczkowska, M. (2015). Rolnictwo ekologiczne - szanse i perspektywy rozwoju [Organic farming - opportunities and development perspectives]. Probl. Hig. Epidem., 96(2), 370-376. DOI: 10.15678/ ZNUEK.2017.0961.0108 [in Polish].

Grzybowska-Brzezińska, M. (2013). Wpływ instrumentów marketingu ekologicznego na zachowania konsumentów na rynku produktów spożywczych [The impact of ecological marketing instruments on consumer behavior on the food market]. Zesz. Nauk. Uniw. Szczec. Probl. Zarz. Fin. Market., 775(30), 47-58. DOI: article-e51db789-9aaf-4f84-9e74-950061a09806 [in Polish].

Grzybowska-Brzezińska, M., Rudzewicz, A. (2015). Environmental management systems in food processing and production as a source of product value for the customer on the organic food market. Int. J. Bus. Perform. Manag., 16(2/3), 304-320. DOI: https://doi.org/10.1504/ IJBPM.2015.068727

Katz, M. L., Shapiro, C. (1985). Network Externalities, Competition and Compatibility. Am. Econ. Rev., 75(3), 424-440.

Kuberska, D., Grzybowska-Brzezińska, M. (2017). A retrospective approach to cluster development in the context of the marketing chain in the Polish organic food market. J. Agribus. Rural Dev., 3(45), 591-599. DOI: 10.17306/J. JARD.2017.00371

Michalczyk, J. (2016). Rynek żywności ekologicznej w warunkach członkostwa Polski w Unii Europejskiej [Organic food market in the conditions of Poland's membership in the European Union]. Prace Nauk. Uniw. Ekon. Wroc., 448, 178-192. DOI: 10.15611/2016.448.14 [in Polish].

Łuczka, W. (2016). The changes on the organic food market. J. Agribus. Rural Dev., 4(42), 597-605. DOI: 10.17306/J. JARD.2016.086

McFadden, J. R., Huffman, W. E. (2017). Willingness-to-pay for natural, organic, and conventional foods: The effect of information and meaningful labels. Food Policy, 68, 214-232.

Przybylak, K. (2016). Rynek żywności ekologicznej w Polsce w 2015 roku. Najnowsze dane w pigułce [The organic food market in Poland in 2015. The latest data at a glance]. Retrieved from: http://biokurier.pl/aktualnosci/3350-rynekzywnosci-ekologicznej-w-polsce-w-2015-rokunajnowsze-dane-w-pigulce [in Polish].

Skowron, S. (2013). Marketing w sieci organizacyjnej na przykładzie klastra Doliny Ekologicznej Żywności [Marketing in the organizational network on the example of the cluster of the Ecological Food Valley]. Zesz. Nauk. Uniw. Szczec. Probl. Zarz. Fin. Market., 775(30), 235-248 [in Polish].

Skowron, S. (2015). Marketing zintegrowany w sieciach organizacyjnych [Integrated marketing in organizational networks]. Zesz. Nauk. Uniw. Szczec. Stud. Prace Wydz. Nauk Ekon. Zarz., 39(2), 221-233 [in Polish].

Zuba, M. (2011). Szanse i bariery w integracji łańcucha żywności ekologicznej w Polsce [Opportunities and barriers to the integration of the organic food chain in Poland]. Zesz. Nauk. WSEI Ser. Ekon., 3(1), 261-288 [in Polish]. 